\title{
The Prevalence of Surgical Wound Infection in Post-Mandibular Resection of Ameloblastoma Patients
}

\section{Prevalensi Infeksi Luka Operasi Pasca Reseksi Mandibula Pada Pasien Ameloblastoma}

\author{
Dani Ginanjar, Abel Tasman Yuza, Winarno Priyanto \\ Oral and Maxillofacial Surgery Department, \\ Faculty of Dentistry, Universitas Padjadjaran, \\ Jl. Sekeloa Sel. I No.1, Lebakgede, Kecamatan Coblong, Kota Bandung, \\ Jawa Barat 40132, Indonesia \\ E-mail: Dani18003@mail.unpad.ac.id
}

\begin{abstract}
Ameloblastoma, a common form of odontogenic tumor, is usually treated by surgery. However, wound infections remain a significant source of postoperative morbidity, accounting for about a quarter of the total number of nosocomial conditions. Surgical wound infection (SWI) is common after surgery, and in particular, wound infection has been linked with an intraoral surgical opening in 20-40-year-old patients. Common incisional closure complications in oral and maxillofacial surgery include postoperative wound infection, dehiscence, formation of hematomas, and skin flap necrosis, which lead to delayed healing of the incision. The data relating to the incidence of post-mandible resection SWI in Dr. Hasan Sadikin Bandung Hospital are not yet known. Therefore, the objective of this research was to assess the incidence of SWI in ameloblastoma patients after mandible resection treatment. This research adopted an observational and descriptive approach. Based on the inclusion and exclusion criteria, the research subjects were recruited between January 2018 and December 2019. This study showed the occurrence of SWI in 7 patients ( 2 men and five women) who had mandibular resection treatment for ameloblastoma and whose age range was 30-40 years. The results also revealed that the surgical openings in these patients were intraoral. In conclusion, findings demonstrated a higher prevalence of SWI in women after mandibular resection treatment than in men.
\end{abstract}

Keywords: Surgical wound infection, ameloblastoma, mandibular resection

\begin{abstract}
Abstrak
Infeksi luka operasi (ILO) adalah infeksi yang sering terjadi pasca pembedahan. Salah satu kondisi yang membutuhkan pembedahan adalah salah satu tumor odontogenik, ameloblastoma. Tindakan pembedahan yang dilakukan adalah hemimandibulektomi atau pengangkatan sebagian tulang mandibula. Data terkait insidensi ILO pasca tindakan ini di RSUP dr. Hasan Sadikin Bandung belum diketahui, sehingga laporan ini bertujuan untuk mengetahui insidensi ILO pada pasien dengan ameloblastoma pasca dilakukan reseksi mandibula. Penelitian ini merupakan penelitian observasional dengan pendekatan deskriptif yang dilakukan di RSUP dr. Hasan Sadikin Bandung. Penentuan subjek penelitian dilakukan dengan total sampling dengan memperhatikan beberapa kriteria eksklusi dan inklusi selama Januari 2018-Desember 2019. Hasil penelitian ini menunjukkan adanya ILO pada 7 pasien dengan ameloblastoma, tepatnya pada 2 pasien laki-laki dan 5 pasien perempuan yang telah dilakukan reseksi mandibula dengan rentang usia 10-40 tahun. Hasil penelitian juga menunjukkan bahwa pembukaan operasi pada ketujuh pasien tersebut dilakukan di intraoral. Kesimpulan penelitian ini adalah prevalensi terjadinya infeksi pasca reseksi mandibula lebih tinggi pada perempuan dibandingkan laki-laki, ILO pasca tindakan reseksi mandibula terjadi pada pembukaan operasi secara intraoral dan pada pasien berusia 20-30 dan 30-40 tahun.
\end{abstract}

Kata kunci: Infeksi luka operasi, ameloblastoma, reseksi mandibula 


\section{INTRODUCTION}

Surgical wound infection (SWI) is a common occurrence in postoperative patients. ${ }^{1}$ A World Health Organization (WHO) survey reported that the global incidence rate of surgical site infection (SSI) ranged between $5 \%$ and $15 \% .^{2}$ In addition, WHO data shows that $5 \%$ to $34 \%$ of all nosocomial infections are SWI3. According to Indonesia Health Department, in 2011, the incidence rate of SWI was 55.1\%.

Furthermore, there are some incident factors of SWI in patients, such as diabetes mellitus, obesity, severe malnutrition, wound location concerns such as shaving the operation area, poor blood location in the surgical site and wound contamination. Also, surgery duration, prophylactic antibiotics, the ventilation of the surgery room, and surgical technique could impact SWI. ${ }^{3}$ Furthermore, the high incidence of SWI in post-surgery patients necessitates precautions to ensure the safety of surgical patients. ${ }^{4}$ Prevention of SWI by reducing the incidence of infection is a crucial task for patients, health workers, visitors, and health care facilities. ${ }^{5}$ For example, patients with other underlying clinical conditions such as diabetes mellitus, malnutrition, infection, or obesity can be initially treated for these conditions to reduce the incidence rate of SWI. ${ }^{3}$ Also, the nurses may help reduce the incidence of SWI by ensuring they adopt the proper wound treatment procedure following Standard Operating Procedures (SOP). ${ }^{6}$

Ameloblastoma is a common type of odontogenic tumor, accounting for $49 \%$ of cases of odontogenic tumors. $^{7}$ The frequency of occurrence of ameloblastoma from the mandible and maxilla varied, respectively, from $8-20 \%$ to $99 \%$. ${ }^{8,9,10,11}$ Furthermore, ameloblastoma is benign but locally invasive with a high recurrence if the surgical excision was not correctly performed. Mandible resection is a surgical procedure to resect or lift the mandible, either partially or totally, and it can be divided into various types, distinguished by thickness and resection level.

Hemi-mandibulectomy is one of the mandibulectomy procedures to lift some mandible bone. It resects most or half of the mandible, including condyloideus processus, coronoideus processus, the mandible ramus, and part of the mandible corpus on one jaw side. Currently, there is no data on SWI relating to mandible operation procedures at Dr. Hasan Sadikin.

\section{MATERIALS AND METHODS}

The observational study received ethical clearance from the Research Ethics Committee of Padjadjaran University with No. 782/UN6.KEP/EC/2020.
Furthermore, based on the exclusion and inclusion criteria, the subjects were recruited by the total sampling method between January 2018 and December 2019. The research subjects were mainly ameloblastoma patients who had mandibular resection in RSHS.

Included in the study are patients diagnosed with ameloblastoma based on clinical and histopathological examination, who had mandibular resection by intraoral and extraoral opening, and received treatment in the Oral and Maxillofacial Surgery Department Dr. Hasan Sadikin Bandung Hospital. Excluded were patients who failed to show up for one week after the surgical operation.

Data were gathered from patient records at Dr. Hasan Sadikin Bandung Hospital's Oral and Maxillofacial Surgery Department. The data was subjected to several processes that included editing, coding, data entry, and cleaning. Numerical information is expressed in standard deviation, and categorical data are represented in proportion and percentage $(\%)$. Data analysis was done with statistical programs where applicable.

\section{RESULTS}

The results showed the occurrence of SWI in 7 patients diagnosed with ameloblastoma following a mandibular resection treatment at the Oral and Maxillofacial Surgery Department between January 2018 and December 2019. The SWI patients consisted of two men $(28.5 \%)$ and five women $(71.5 \%)$. The age distribution of the confirmed SWI patients is 10-20 years ( 1 patient, $14.4 \%$ ), 20-30 years ( 3 patients, $42.8 \%$ ), and $30-40$ years ( 3 patients, $42.8 \%$ ), with the oldest patient being 46 years old, while the youngest was 19 years old (Table 1).

The prevalence of SWI based on the opening of the operating area was intraoral opening in 7 patients $(100 \%)$, and no patient had an extraoral opening (Table 2).

\section{DISCUSSION}

Based on the Dorland medical dictionary, infection is the entry of microorganisms that multiply in body tissues, causing inflammation. ${ }^{11}$ Wound infection is the most commonly found infection associated with nosocomial. For example, SWI incidence relating to surgical operations can be caused by pathogenic microorganisms that contaminate the surgical wound area during or after the surgery. ${ }^{11}$ Furthermore, the infection is usually accompanied by inflammation and 
is characterized by pus discharge from the wound site. $^{3}$

The longer the hospitalization before surgery, the more susceptible the patient is to wound infection. The use of prophylactic antibiotics can decrease infection risk by $75 \%$. The duration of the operation, the level of tissue trauma during the procedure, and the introduction of foreign objects such as threads or drains can all influence the likelihood of SWI and the likelihood of subsequent wound damage.

Nurses have an essential role in surgical wound management, and this role includes wound observation and patient assessment, dressing changes, and general wound care. In addition, some risk factors, such as patients' age and underlying clinical conditions like diabetes mellitus and immunodeficiency, need to be considered concerning SWI incidence. For example, immunodeficiency and malnutrition have been shown to influence surgical site infection (SSI) in geriatrics. ${ }^{3}$

Ameloblastoma is the most commonly found odontogenic tumor, with $49 \%$ of odontogenic tumor cases. Cusack first discovered ameloblastoma in $1827 .{ }^{7}$ Though it was initially referred to as Adamantinoma by a French doctor, Louis-Charles Malassez, in 1885, it was finally named ameloblastoma in 1933 by Ivery and Churchill.
The majority of ameloblastomas (95\%) are unilateral and occur in the posterior of the jaw $(85 \%)$. Furthermore, Pinbord and Clausen classified odontogenic tumors based on clinical and histological appearance into benign, malignant, and intermediate (borderline) tumors. The tumor size and characteristics can give information about the prognosis of an ameloblastoma patient. The prognosis is good for ameloblastomas that have not invaded the mandibular inferior margin cortex, and treatment can be done by a minimally invasive procedure, namely enucleation. The procedure could be either marginal, segmental, hemi-mandibulectomy, or mandibulectomy. In contrast, malignant ameloblastomas are usually characterized by a poor prognosis. ${ }^{10}$

In this research, $30 \%$ of ameloblastoma patients who had mandibular resection surgery had SWI; 4 patients during 2018 had definitive mandibular treatment, and three patients during 2019.

Based on the findings of this study, it is possible to conclude that SWI is more common in female patients than in males and that all infected patients had an intraoral opening surgical procedure. Furthermore, most patients with SWI following a mandibular resection were aged $20-30$ and $30-40$ years old.

\section{TABLES}

$\underline{\text { Table 1. Research characteristic data based on gender and age }}$

\begin{tabular}{|c|c|c|c|}
\hline No & $\begin{array}{l}\text { Research } \\
\text { Characteristics }\end{array}$ & Total & Percentage \\
\hline & Gender & & \\
\hline 1. & Men & 2 & $28.5 \%$ \\
\hline 2. & $\begin{array}{l}\text { Women } \\
\text { Age }\end{array}$ & 5 & $71.5 \%$ \\
\hline 1 & $10-20$ years & 1 & $14.4 \%$ \\
\hline 2 & 20-30 years & 3 & $42.8 \%$ \\
\hline 3 & 20-30 years & 3 & $42.8 \%$ \\
\hline & Total & 7 & 100 \\
\hline
\end{tabular}

Table 2. Research characteristics data based on approach surgery.

\begin{tabular}{llcl}
\hline No & $\begin{array}{l}\text { Research } \\
\text { Characteristics }\end{array}$ & Total & Percentage \\
\hline \multicolumn{4}{l}{ Opening of the operation area } \\
1. & Intra Oral & 7 & $100 \%$ \\
2. & Extra Oral & 0 & $0 \%$ \\
\hline & Total & 7 & 100 \\
\hline
\end{tabular}




\section{REFERENCES}

1. Mulu W, Kibru G, Beyene G, Damtie M. Postoperative nosocomial infections and antimicrobial resistance pattern of bacteria isolate among patients admitted at Felege Hiwot Referral Hospital. Ethiop. J. Health Sci 2012; 22(1): 7-18.

2. Ana KD, Wulansari HI. The correlation between nursing knowledge of surgical wound infections and the method of surgical wound infection prevention in inpatient ward of Prima Husada Hospital. J. Glob. Health 2019; 4(1): 62-7.

3. Abdulai AE. Treatment of ameloblastoma of the jaws in children. Ghana Med. J. 2011; 45(1): 35-7

4. Ruslin M, Hendra FN, Vojdani A, Hardjosantoso D, Gazali M, Tajrin A, Forouzanfar T. The epidemiology, treatment, and complication of ameloblastoma in East-Indonesia: 6 years retrospective study. Med. Oral. Patol. Oral Cir Buccal 2018; 23(1): 54-8.

5. McClary AC, West RB, McClary AC, Pollack JR, Fischbein NJ, Holsinger CF, Sirjani D. Ameloblastoma: a clinical review and trends in management Eur. Arch. Oto-Rhino-Laryngol 2016, 273(7): 164961.
6. Avon SL, McComb J, Clokie C. Ameloblastic carcinoma: case report and literature review. J. Can. Dent. Assoc. 2003; 69(9): 573-6.

7. Nalabolu GR., Mohiddin A, Hiremath SK, Manyam R, Bharath TS, Raju PR. Epidemiological study of odontogenic tumors: An institutional experience. J. Infect. Public 2017: 10(3): 324-30.

8. Dahesihdewi A. Surveilans HAI'S di Rumah Sakit. Continuing Nurse Education. Program Studi Profesi Nurse Angkatan XXII UMY, 2015

9. Novelia S, Aulya Y, Agustini D. Factors related to the incidence of Cesarean Section Surgical Site Infection (CS SSI) At Harapan Jayakarta Hospital in 2019. SJK 2021; 10(1): 952-63.

10. Riyadi S, Harmoko H. Standard operating procedure dalam praktik klinik keperawatan dasar. Yogyakarta: Pustaka Belajar, 2012.

11. Rosaliya Y, Suryani M. Faktor-faktor yang mempengaruhi kejadian infeksi nosokomial pada pasien luka post operasi di RSUD Tugurejo Semarang. Karya Ilmiah STIKES Telogorejo 2012; 1(1): $1-10$ 